\title{
Study on effect of integrated nutrient management on growth and yield of cauliflower (Brassica oleracea var. botrytis $\mathrm{L}$.)
}

\author{
Rohit Pawar* and Santosh Barkule \\ 84/B, Baba Sadan, Jotirling Colony, Golibar Maidan, Godoli, Satara-415001 (Maharashtra), INDIA \\ *Corresponding author. E-mail: rohitpawar0099@gmail.com \\ Received: April 26, 2016; Revised received: November 24, 2016; Accepted: February 19, 2017
}

\begin{abstract}
In order to investigate the effect of integrated nutrient management on growth and yield components in Cauliflower, Brassica oleracea var. botrytis L., cv. Pusa snowball- 16, an experiment was conducted using Randomized Block Design with two replications. The experiment comprised of 14 different treatment combinations comprising of different sources of nutrients including organic, inorganic and bio-fertilizers. The growth parameters like height of plant $(12.10,23.50 \mathrm{~cm})$, number of leaves per plant $(9.10,14.40)$ and diameter of stem $(1.20,2.10 \mathrm{~cm})$ at 40 and 60 DAT respectively, the days required for curd initiation (62.00 days), days required for curd maturity (85.70 days) and staying period of curd (9.50 days) were observed maximum in treatment combination $75 \%$ RDF + FYM + Azotobacter + Azospirillum $\left(\mathrm{T}_{6}\right)$. The yield parameters like weight of curd per plot $(17.50 \mathrm{~kg} / \mathrm{plot})$ and yield per hectare $(180.04 \mathrm{q} / \mathrm{ha})$ which was increased 44.10 per cent over RDF. From the studies it can be inferred that the application of $75 \%$ RDF + FYM along with Azospirillum and Azotobactor was found to be the most effective treatment combination for getting enhanced growth and yield in cauliflower.
\end{abstract}

Keywords: Cauliflower, Fertilizers, Growth, Yield

\section{INTRODUCTION}

Vegetable plays an important role in human nutrition. These are indispensable group of food, providing vitamins, minerals, protein, carbohydrates and fibers in the diet, besides having medicinal value and provide nutritional security. Among different vegetables, cauliflower (Brassica oleracea var. botrytis L.) is one of the most important winter vegetable among the cole crops which belongs to the genus Brassica of the family Cruciferae. Cauliflower is essentially a cold weather hardy crop and thrives best in cool and moist climate. Cauliflower is the fifth most important vegetable crop in India, primarily grown in the winter season. In India cauliflower grown over an area 433.9 thousand ha with production of about 5873.3 thousand $\mathrm{MT} / \mathrm{ha}$ and productivity is $19.8 \mathrm{MT} / \mathrm{ha}$. The dramatic increase in vegetable productivity and the increase in fertilizer consumption point to the crucial role of fertilizers. In 2014 , the highest area and production of cauliflower is in West Bengal ie.73.6 thousand ha, 1879.0 thousand $\mathrm{MT} /$ ha respectively (Anonymous, 2014).Cauliflower is being grown round the year for its white and tender curd. It is widely cultivated all over India and abroad for its special nutritive values, high productivity and wider adaptability under different ecological conditions. Like other vegetable crops of the family cauliflower are a heavy feeder of mineral elements, it removes large amount of macronutrients from the soil. Heavy manuring has been recommended for getting good yield of cauliflower by different workers in India (Roy, 1981, Randhawa and Khurana, 1983). Mineral nutrition does play an important role in influencing the quality of crops and it is fact that the soil health deteriorates due to continuous use of chemical fertilizers, (Savci, 2012). The integrated nutrient management paves the way to overcome these problems, which involves conjunctive use of chemical fertilizers and organic manures to sustain crop production as well as maintenance of soil health (Nanjappa et al., 2001). Systematic approach to nutrient management by tapping all possible sources of organic and inorganic in a judicious manner to maintain soil fertility and crop productivity is the essence of integrated nutrient management (INM).

In addition, utilization of bio-fertilizers, which have a ability to enrich the soil with beneficial microorganisms as well as to mobilize the nutritionally important elements like $\mathrm{P}, \mathrm{K}$ and micronutrients like $\mathrm{Zn}$, Mo (Mishra and Dash, 2014) from non-usable to usable forms through biological processes resulting in enhanced production of fruits and vegetables offer an alternative. .The use of biofertilizers in combination with chemical fertilizers and organic manures offers a great opportunity to increase the production as well as quality of cauliflower. Bio-fertilizers can symbiotically associate with plant roots. Involved microorganisms could readily and safely convert complex organic material into simple compounds, so that they are easily 
taken up by the plants. Microorganism function is in long duration, causing the soil fertility. It maintains the natural habitat of the soil. It increases crops yield by $20-30 \%$, replaces chemical nitrogen and phosphorus by $25 \%$ and stimulates plant growth. It can also provide protection against drought and some soil-borne diseases (Purkayastha et al., 1998). Among the nitrogen fixing bacteria, Azotobacter, not only provides nitrogen, but also synthesizes growth promoting hormones such as IAA and GA. Azospirillum also helps in plant growth and increases the yield of crops by improving root development, mineral uptake etc. The positive role of these bio-fertilizers has been recorded in many vegetables and spice crops by different scientists. To maintain long term soil health and productivity there is a need for integrated nutrient management through manures and bio-fertilizers apart from costly chemical fertilizers for better yield of the crop (Mondal et al., 2003).

Therefore, the present investigations were undertaken to study the effect of inorganic fertilizers alone and in combination with different bio-fertilizers on growth and yield of cauliflower.

\section{MATERIALS AND METHODS}

The present investigation on effect of integrated nutrient management on growth and yield of cauliflower was carried out at vegetable Research Farm of Department of Horticulture, College of Agriculture, Latur, under Vasantrao Naik Marathawada krishi vidyapeeth Parbhani in Maharashtra. The experiment was laid out in randomized block design with two replications comprising of fourteen treatment combinations (Table 1). The seeds were sown in raised nursery beds. After sowing, seeds were covered with a thin film of soil mixed with Farm Yard Manure. Thereafter, paddy straws mulching was incorporated to reduce moisture loss. The beds were irrigated twice a day with the help of water can to maintain optimum moisture in soil.

Twenty five days old seedlings were used for transplanting in the main field. The required quantity of bio -fertilizers such as Azotobactor and Azospirillum (10

Table 1. Treatment details and their symbols.

\begin{tabular}{|c|c|}
\hline Treatments details & Symbol \\
\hline $100 \%$ RDF (120:80:40 kg/ha.) & $\mathrm{T}_{1}$ \\
\hline $100 \% \mathrm{RDF}+\mathrm{FYM}+$ Azotobacter + Azospirillum & $\mathrm{T}_{2}$ \\
\hline $100 \% \mathrm{RDF}+$ Azotobacter + Azospirillum & $\mathrm{T}_{3}$ \\
\hline $100 \% \mathrm{RDF}+\mathrm{FYM}+$ Azotobacter & $\mathrm{T}_{4}$ \\
\hline $100 \%$ RDF+ FYM + Azospirillum & $\mathrm{T}_{5}$ \\
\hline $75 \% \mathrm{RDF}+\mathrm{FYM}+$ Azotobacter + Azospirillum & $\mathrm{T}_{6}$ \\
\hline $75 \%$ RDF + Azotobacter + Azospirillum & $\mathrm{T}_{7}$ \\
\hline $75 \%$ RDF+ FYM + Azotobacter & $\mathrm{T}_{8}$ \\
\hline $75 \%$ RDF+ FYM + Azospirillum & $\mathrm{T}_{9}$ \\
\hline $50 \% \mathrm{RDF}+\mathrm{FYM}+$ Azotobacter + Azospirillum & $\mathrm{T}_{10}$ \\
\hline $50 \% \mathrm{RDF}+\mathrm{FYM}+$ Azotobacter & $\mathrm{T}_{11}$ \\
\hline $50 \% \mathrm{RDF}+\mathrm{FYM}+$ Azospirillum & $\mathrm{T}_{12}$ \\
\hline $50 \% \mathrm{RDF}+$ Azotobacter + Azospirillum & $\mathrm{T}_{13}$ \\
\hline Control. & $\mathrm{T}_{14}$ \\
\hline
\end{tabular}

$\mathrm{kg} / \mathrm{ha}$ ) was mixed in soil and given to the respective plots. The FYM (10 t/ha) and NPK (120:80:40 kg/ha) was applied as per the decided treatments in which half dose of nitrogen through urea along with the full dose of phosphorous through single super phosphate and potassium through murate of potash was applied. The half dose of nitrogen was given as per treatments after 30 days of transplanting. Healthy uniform seedlings of four weeks age were selected for transplanting and they were treated with bavistin@2 g /lit and transplanted in the plot size $3.6 \mathrm{~m} \times 2.7 \mathrm{~m}$ at spacing of 60 x $45 \mathrm{~cm}$. Thus, the numbers of plants per plot were 36 . Light irrigation was given immediately after transplanting.

The observations were recorded for growth and yield attributing characters viz. plant height $(\mathrm{cm})$, stem diameter $(\mathrm{cm})$,number of leaves per plant, leaf area per plant $\left(\mathrm{cm}^{2}\right)$, number of days taken to curd initiation, number of days taken to curd maturity, staying period of curd, yield per plot $(\mathrm{kg})$, yield per hectare $(\mathrm{q} / \mathrm{ha})$. Five plants in each treatment combination and in each replication were randomly selected and tagged properly for recording various observations.

The experimental data of all the parameters was subjected to statistical analysis for proper interpretation. The statistical analysis of data in respect of the growth and yield components was done according to the standard procedure given for randomized block design by Panse and Sukhatme (1967).

\section{RESULTS AND DISCUSSION}

The data pertaining to the various observations on growth and yield parameters in cauliflower have been shown in Table 2a, 2b, 3 and 4. Vegetative growth of a cauliflower plant was characterized by plant height, number of leaves, diameter of stem etc., which influenced the total yield of crop.

Growth characters: Marked effect in height of the plant was obtained when supplied with inorganic fertilizers in combination with organic manure and biofertilizers than sole application of inorganic fertilizers. The data revealed that the height of plant was significantly influenced due to different treatments of INM at different growth stages. At 20 Days after Transplanting (DAT), the maximum plant height $(7.20 \mathrm{~cm})$ was recorded in the treatment of $100 \% \mathrm{RDF}+$ Azotobacter + Azospirillum $\left(\mathrm{T}_{3}\right)$, and it was at par with treatments $\mathrm{T}_{4}$, $\mathrm{T}_{2}, \mathrm{~T}_{1}, \mathrm{~T}_{6}, \mathrm{~T}_{5}, \mathrm{~T}_{7}$ and $\mathrm{T}_{8}$. Whereas, the minimum plant height $(4.25 \mathrm{~cm})$ was recorded in the treatment $\mathrm{T}_{10}$. At 40 DAT, the treatment of $75 \% \mathrm{RDF}+\mathrm{FYM}+$ Azotobacter + Azospirillum $\left(\mathrm{T}_{6}\right)$ has recorded maximum plant height $(12.10 \mathrm{~cm})$ while, rest of the treatments were at par except $T_{10}$ and $T_{14}$. The minimum plant height $(8.60 \mathrm{~cm})$ was recorded in treatment control $\left(\mathrm{T}_{14}\right)$. At $60 \mathrm{DAT}$, the treatment of $75 \% \mathrm{RDF}+\mathrm{FYM}$ + Azotobacter + Azospirillum $\left(\mathrm{T}_{6}\right)$ was recorded maxi- 
Rohit Pawar and Santosh Barkule / J. Appl. \& Nat. Sci. 9 (1): 520 - 525 (2017)

Table 2 a. Effect of different INM treatments on growth parameters of cauliflower plant at different growth stages.

\begin{tabular}{|c|c|c|c|c|c|c|c|}
\hline \multirow{2}{*}{$\begin{array}{l}\text { Tr. } \\
\text { No. }\end{array}$} & \multirow{2}{*}{ Treatments } & \multicolumn{3}{|c|}{ Plant Height (cm) } & \multicolumn{3}{|c|}{ Number of leaves per plant } \\
\hline & & 20 DAT & 40 DAT & 60 DAT & 20 DAT & 40 DAT & $60 \mathrm{DAT}$ \\
\hline $\mathrm{T}_{1}$ & $100 \%$ RDF (120:80:40 kg/ha.) & 5.90 & 11.30 & 17.80 & 6.00 & 7.50 & 12.50 \\
\hline $\mathrm{T}_{2}$ & $100 \% \mathrm{RDF}+\mathrm{FYM}+$ Azotobacter + Azospirillum & 5.95 & 12.00 & 21.40 & 5.10 & 8.40 & 11.70 \\
\hline $\mathrm{T}_{3}$ & $100 \% \mathrm{RDF}+$ Azotobacter + Azospirillum & 7.20 & 11.60 & 20.00 & 6.20 & 8.20 & 12.00 \\
\hline $\mathrm{T}_{4}$ & $100 \% \mathrm{RDF}+\mathrm{FYM}+$ Azotobacter & 6.30 & 11.60 & 21.30 & 5.40 & 7.20 & 12.60 \\
\hline $\mathrm{T}_{5}$ & $100 \%$ RDF+ FYM + Azospirillum & 5.60 & 10.60 & 18.50 & 5.60 & 7.70 & 11.80 \\
\hline $\mathrm{T}_{6}$ & $75 \% \mathrm{RDF}+\mathrm{FYM}+$ Azotobacter + Azospirillum & 5.85 & 12.10 & 23.50 & 5.55 & 9.10 & 14.40 \\
\hline $\mathrm{T}_{7}$ & $75 \% \mathrm{RDF}+$ Azotobacter + Azospirillum & 5.55 & 10.80 & 17.50 & 5.30 & 7.70 & 12.80 \\
\hline $\mathrm{T}_{8}$ & $75 \% \mathrm{RDF}+\mathrm{FYM}+$ Azotobacter & 5.30 & 10.60 & 18.40 & 4.40 & 8.20 & 13.10 \\
\hline $\mathrm{T}_{9}$ & $75 \% \mathrm{RDF}+\mathrm{FYM}+$ Azospirillum & 5.10 & 9.60 & 17.50 & 4.70 & 7.00 & 11.40 \\
\hline $\mathrm{T}_{10}$ & $50 \% \mathrm{RDF}+\mathrm{FYM}+$ Azotobacter + Azospirillum & 4.25 & 8.70 & 16.30 & 4.50 & 6.90 & 11.90 \\
\hline $\mathrm{T}_{11}$ & $50 \% \mathrm{RDF}+\mathrm{FYM}+$ Azotobacter & 4.40 & 9.40 & 15.30 & 4.90 & 7.60 & 12.70 \\
\hline $\mathrm{T}_{12}$ & $50 \% \mathrm{RDF}+\mathrm{FYM}+$ Azospirillum & 5.25 & 9.70 & 16.60 & 5.00 & 7.20 & 12.20 \\
\hline $\mathrm{T}_{13}$ & $50 \% \mathrm{RDF}+$ Azotobacter + Azospirillum & 4.55 & 9.40 & 16.30 & 3.90 & 6.80 & 11.80 \\
\hline \multirow[t]{3}{*}{$\mathrm{T}_{14}$} & Control & 4.50 & 8.60 & 14.90 & 4.50 & 6.20 & 11.20 \\
\hline & S.E. \pm & 0.63 & 0.88 & 1.05 & 0.34 & 0.39 & 0.48 \\
\hline & C.D. at $5 \%$ & 1.92 & 2.70 & 3.22 & 1.06 & 1.19 & 1.49 \\
\hline
\end{tabular}

mum plant height $(23.50 \mathrm{~cm})$ and treatments $\mathrm{T}_{2}$ and $\mathrm{T}_{4}$ were found statistically at par and recorded plant height of $21.40 \mathrm{~cm}$ and $21.30 \mathrm{~cm}$ respectively. The least plant height $(14.90 \mathrm{~cm})$ was recorded in treatment control $\left(\mathrm{T}_{14}\right)$.

The maximum increase in plant height in the treatment $\mathrm{T}_{6}$ could be due to nitrogen being a constituent of amino acids, nucleotides, nucleic acids, a number of coenzymes, auxins, cytokinins and alkaloids, induces cell elongation, cell enlargement and cell division. The increase in plant height could be because of certain growth promoting substances secreted by the Azospirillum, which in turn, might have led to better root development, better transportation of water, uptake and deposition of nutrients. Thus, sufficient nutrient availability required for better growth of plants which in turns leads to increase in height of plants. The similar trend of result was also reported by Sable and Bhamare (2007), who reported that, the combined application of Azotobacter and Azospirillum increase the plant height. These results are also in agreement with the finding of
Shree et al. (2014).

Maximum numbers of leaves At 20 DAT, the average numbers of leaves were maximum (6.20) in treatment of $100 \% \mathrm{RDF}+$ Azotobacter + Azospirillium $\left(\mathrm{T}_{3}\right)$ while, the treatments $\mathrm{T}_{1}, \mathrm{~T}_{5}, \mathrm{~T}_{6}, \mathrm{~T}_{4}$ and $\mathrm{T}_{7}$ were statistically at par. The treatment $\mathrm{T}_{13}$ was recorded the least (3.90) number of leaves. At $40 \mathrm{DAT}$, the average numbers of leaves were maximum (9.10) in treatment of 75 $\% \mathrm{RDF}+\mathrm{FYM}+$ Azotobacter + Azospirillium $\left(\mathrm{T}_{6}\right)$ while, the treatments $\mathrm{T}_{2}, \mathrm{~T}_{3}$ and $\mathrm{T}_{8}$ were statistically at par. The treatment control $\left(\mathrm{T}_{14}\right)$ has recorded the least (6.20) number of leaves. At 60 DAT, the treatment of $75 \% \mathrm{RDF}+\mathrm{FYM}+$ Azotobacter + Azospirillium $\left(\mathrm{T}_{6}\right)$ recorded maximum leaves per plant (14.40) and it was at par with the treatment $\mathrm{T}_{8}$. The minimum numbers of leaves (11.20) were recorded in the treatment control $\left(\mathrm{T}_{14}\right)$.

The maximum number of leaves in treatment $\mathrm{T}_{6}$ could be attributed to timely supply of nutrients particularly nitrogen which is required for vegetative growth of plant in this treatment. The FYM as a source of organ-

Table 2 b. Effect of different INM treatments on growth parameters of cauliflower plant at different growth stages.

\begin{tabular}{|c|c|c|c|c|c|c|c|}
\hline \multirow{2}{*}{$\begin{array}{l}\text { Tr. } \\
\text { No. }\end{array}$} & \multirow{2}{*}{ Treatments } & \multicolumn{3}{|c|}{ Diameter of stem (cm) } & \multicolumn{3}{|c|}{ Leaf area per plant $\left(\mathrm{cm}^{2}\right)$} \\
\hline & & 20 DAT & 40 DAT & 60 DAT & 20 DAT & 40 DAT & 60 DAT \\
\hline $\mathrm{T}_{1}$ & $100 \%$ RDF (120:80:40 kg/ha.) & 0.65 & 1.10 & 1.70 & 121.95 & 3372.50 & 12298 \\
\hline $\mathrm{T}_{2}$ & $100 \% \mathrm{RDF}+\mathrm{FYM}+$ Azotobacter + Azospirillum & 0.60 & 0.90 & 1.70 & 134.20 & 3777.10 & 13678 \\
\hline $\mathrm{T}_{3}$ & $100 \% \mathrm{RDF}+$ Azotobacter + Azospirillum & 0.65 & 1.00 & 1.75 & 129.20 & 3291.25 & 12457 \\
\hline $\mathrm{T}_{4}$ & $100 \% \mathrm{RDF}+\mathrm{FYM}+$ Azotobacter & 0.50 & 0.90 & 1.55 & 103.10 & 3542.70 & 12108 \\
\hline $\mathrm{T}_{5}$ & $100 \% \mathrm{RDF}+\mathrm{FYM}+$ Azospirillum & 0.55 & 1.00 & 1.80 & 118.90 & 3265.00 & 11867 \\
\hline $\mathrm{T}_{6}$ & $75 \% \mathrm{RDF}+\mathrm{FYM}+$ Azotobacter + Azospirillum & 0.55 & 1.20 & 2.10 & 114.80 & 3483.70 & 13033 \\
\hline $\mathrm{T}_{7}$ & $75 \% \mathrm{RDF}+$ Azotobacter + Azospirillum & 0.50 & 1.00 & 1.75 & 104.00 & 3318.00 & 12229 \\
\hline $\mathrm{T}_{8}$ & $75 \% \mathrm{RDF}+\mathrm{FYM}+$ Azotobacter & 0.50 & 1.20 & 1.85 & 96.10 & 3253.10 & 11991 \\
\hline $\mathrm{T}_{9}$ & $75 \% \mathrm{RDF}+\mathrm{FYM}+$ Azospirillum & 0.50 & 0.90 & 1.60 & 91.47 & 2594.90 & 10434 \\
\hline $\mathrm{T}_{10}$ & $50 \% \mathrm{RDF}+\mathrm{FYM}+$ Azotobacter + Azospirillum & 0.55 & 0.90 & 1.65 & 105.85 & 2643.00 & 11480 \\
\hline $\mathrm{T}_{11}$ & $50 \% \mathrm{RDF}+\mathrm{FYM}+$ Azotobacter & 0.60 & 0.90 & 1.65 & 106.80 & 2739.70 & 12549 \\
\hline $\mathrm{T}_{12}$ & $50 \% \mathrm{RDF}+\mathrm{FYM}+$ Azospirillum & 0.45 & 0.90 & 1.80 & 96.75 & 2781.70 & 11393 \\
\hline $\mathrm{T}_{13}$ & $50 \% \mathrm{RDF}+$ Azotobacter + Azospirillum & 0.45 & 0.90 & 1.75 & 84.55 & 2306.70 & 12784 \\
\hline \multirow[t]{3}{*}{$\mathrm{T}_{14}$} & Control & 0.45 & 0.80 & 1.40 & 83.60 & 2132.40 & 10182 \\
\hline & S.E. \pm & 0.04 & 0.08 & 0.12 & 8.46 & 829.21 & 1832 \\
\hline & C.D. at $5 \%$ & 0.13 & 0.24 & 0.37 & 25.80 & N.S. & N.S. \\
\hline
\end{tabular}


Table 3. Effect of different INM treatments on curd initiation, curd maturity and staying period of cauliflower.

\begin{tabular}{llccc}
\hline Tr. No. & Treatments & $\begin{array}{c}\text { Days required for curd } \\
\text { initiation }\end{array}$ & $\begin{array}{c}\text { Days required for curd } \\
\text { maturity }\end{array}$ & $\begin{array}{c}\text { Staying period of } \\
\text { curd (Days) }\end{array}$ \\
\hline $\mathrm{T}_{1}$ & $100 \% \mathrm{RDF}(120: 80: 40 \mathrm{~kg} / \mathrm{ha})$. & 70.50 & 90.70 & 7.75 \\
$\mathrm{~T}_{2}$ & $100 \% \mathrm{RDF}+\mathrm{FYM}+A b .+A p$. & 69.80 & 87.10 & 6.25 \\
$\mathrm{~T}_{3}$ & $100 \% \mathrm{RDF}+A b .+A p$. & 66.50 & 89.40 & 6.75 \\
$\mathrm{~T}_{4}$ & $100 \% \mathrm{RDF}+\mathrm{FYM}+A b$. & 67.50 & 89.50 & 6.95 \\
$\mathrm{~T}_{5}$ & $100 \% \mathrm{RDF}+\mathrm{FYM}+A p$. & 69.50 & 89.70 & 7.25 \\
$\mathrm{~T}_{6}$ & $75 \% \mathrm{RDF}+\mathrm{FYM}+A b .+A p$. & 62.00 & 85.70 & 9.25 \\
$\mathrm{~T}_{7}$ & $75 \% \mathrm{RDF}+A b .+A p$. & 68.20 & 86.80 & 7.00 \\
$\mathrm{~T}_{8}$ & $75 \% \mathrm{RDF}+\mathrm{FYM}+A b$. & 66.30 & 89.20 & 8.25 \\
$\mathrm{~T}_{9}$ & $75 \% \mathrm{RDF}+\mathrm{FYM}+A p$. & 66.40 & 89.50 & 6.75 \\
$\mathrm{~T}_{10}$ & $50 \% \mathrm{RDF}+\mathrm{FYM}+A b .+A p$. & 67.30 & 88.80 & 7.75 \\
$\mathrm{~T}_{11}$ & $50 \% \mathrm{RDF}+\mathrm{FYM}+A b$. & 71.80 & 94.90 & 6.75 \\
$\mathrm{~T}_{12}$ & $50 \% \mathrm{RDF}+\mathrm{FYM}+A p$. & 75.50 & 93.80 & 5.75 \\
$\mathrm{~T}_{13}$ & $50 \% \mathrm{RDF}+A b .+A p$. & 75.20 & 96.30 & 6.75 \\
$\mathrm{~T}_{14}$ & Control. & 76.20 & 97.20 & 5.75 \\
& S.E. \pm & 2.43 & 2.21 & 0.52 \\
& C.D. at $5 \%$ & 7.48 & 6.76 & 1.60 \\
\hline
\end{tabular}

ic manure might have helped in development of the physical properties of soil like porosity, aeration and water holding capacity. The soil application of biofertilizers might have helped to increase the biological nitrogen fixation and availability of phosphorus required for strong vegetative growth. Thus, it ultimately leads to production of more number of leaves in this treatment. The minimum number of leaves in control treatment is obvious, might be due to lack of proper amount of nutrient needed for production of more number of leaves. Similar result has been reported by Peerzada et al. (2009) in cabbage. The results are in accordance with the findings of Gurav (2002) who reported that the application of Azotobacter and Azospirillum with inorganic fertilizers significantly increase the 14.12 number of leaves in cabbage.

The different INM treatments produced significant effect on stem diameter. The maximum diameter of stem At 20 DAT, the maximum stem diameter $(0.65$ $\mathrm{cm}$ ) was recorded in $T_{1}$ and $T_{3}$, while, treatments $T_{2}$, $\mathrm{T}_{11}, \mathrm{~T}_{5}, \mathrm{~T}_{6}$ and $\mathrm{T}_{10}$ which was found at par. Minimum stem diameter $(0.45 \mathrm{~cm})$ was recorded in treatments $\mathrm{T}_{12}, \mathrm{~T}_{13}$ and $\mathrm{T}_{14}$. At $40 \mathrm{DAT}$, the maximum stem diameter $(1.20 \mathrm{~cm})$ was observed in $T_{6}$ and $T_{8}$ and it was at par with treatments $T_{1}, T_{3}, T_{5}$ and $T_{7}$. The minimum stem diameter $(0.80 \mathrm{~cm})$ was recorded in treatment control $\left(\mathrm{T}_{14}\right)$. At $60 \mathrm{DAT}$, the maximum stem diameter $(2.10 \mathrm{~cm})$ was observed in treatment of $75 \% \mathrm{RDF}+$ $\mathrm{FYM}+$ Azotobacter + Azospirillium $\left(\mathrm{T}_{6}\right)$ while, the treatments $\mathrm{T}_{8}, \mathrm{~T}_{5}, \mathrm{~T}_{3}$ and $\mathrm{T}_{7}$ were found to be at par with each other. The minimum stem diameter $(1.40 \mathrm{~cm})$ was recorded in treatment control $\left(\mathrm{T}_{14}\right)$. The reason behind this maximum diameter of stem may be due to the more succulence in stem and balanced $\mathrm{C}$ : $\mathrm{N}$ ratio and sufficient supply of available nutrient from the soil. This might be due to less retention in the roots and more translocation to aerial parts for synthesis of protoplasmic protein and other metabolites enabling the expansion of photosynthetic area due to which the di- ameter of stem increased. Similar trend of result was also observed in the experimentation of Sable and Bhamare (2007) who reported that the application of inorganic fertilizers plus bio-fertilizers created a favorable condition and supply sufficient nutrients for proper growth of plant.

The result of present investigation indicated that At 20 DAT, the maximum leaf area per plant $\left(134.20 \mathrm{~cm}^{2}\right)$ was recorded in treatment of $100 \% \mathrm{RDF}+\mathrm{FYM}+$ Azotobacter + Azospirillum $\left(\mathrm{T}_{2}\right)$ while, treatments $\mathrm{T}_{3}$, $\mathrm{T}_{1}, \mathrm{~T}_{5}$ and $\mathrm{T}_{6}$ were at par. The minimum leaf area $\left(83.60 \mathrm{~cm}^{2}\right)$ was observed in treatment control $\left(T_{14}\right)$. The leaf area per plant was not significantly influenced due to different treatments of INM at 40 and 60 DAT. However, maximum leaf area $\left(3777.10 \mathrm{~cm}^{2}\right)$ at 40 DAT and $\left(13678 \mathrm{~cm}^{2}\right)$ at 60 DAT was recorded in treatment of $100 \% \mathrm{RDF}+\mathrm{FYM}+$ Azotobacter + Azospirillum $\left(\mathrm{T}_{2}\right)$ while, the minimum leaf area per plant $\left(2132.40 \mathrm{~cm}^{2}\right)$ at 40 DAT and $\left(10182 \mathrm{~cm}^{2}\right)$ at 60 DAT was recorded in treatment control $\left(\mathrm{T}_{14}\right)$. It indicated that the treatment of application of $100 \%$ RDF have produced the larger leaf area at early stages. This could be attributed to the availability of required quantity of nutrients in general and nitrogen in particular for plants in these treatments. The minimum leaf area $\left(83.60 \mathrm{~cm}^{2}\right)$ in control treatment may be due to lack of required quantity of nitrogen required for production and development of leaves. The non-significant differences in leaf area in advanced stages of crop growth could be due to maximum utilization of absorbed nutrients for completion of vegetative growth of the plant. The scanning of available literature does not show any supporting evidence with the findings of present investigation.

Yield and yield contributing characters: Days required for curd initiation data clearly showed significant variation in days required for curd initiation along with treatments. The minimum days required for curd initiation (62.00 days) were recorded in the treatment 
Table 4. Effect of different INM treatments on curd yield parameters of cauliflower.

\begin{tabular}{llcccc}
\hline Tr. No. & Treatments & $\begin{array}{c}\text { Weight of } \\
\text { curd (g) }\end{array}$ & $\begin{array}{c}\text { Yield per } \\
\text { plot (kg). }\end{array}$ & $\begin{array}{c}\text { Yield per } \\
\text { hectare (q). }\end{array}$ & $\begin{array}{c}\text { Per cent increase/decrease in } \\
\text { yield over RDF }\end{array}$ \\
\hline $\mathrm{T}_{1}$ & $100 \%$ RDF $(120: 80: 40 \mathrm{~kg} / \mathrm{ha})$. & 688.55 & 12.14 & 124.94 & --- \\
$\mathrm{T}_{2}$ & $100 \% \mathrm{RDF}+\mathrm{FYM}+A b .+A p$. & 908.60 & 17.10 & 175.92 & 40.80 \\
$\mathrm{~T}_{3}$ & $100 \% \mathrm{RDF}+A b .+A p$. & 888.60 & 16.54 & 162.13 & 29.77 \\
$\mathrm{~T}_{4}$ & $100 \% \mathrm{RDF}+\mathrm{FYM}+A b$. & 904.15 & 15.50 & 159.48 & 27.65 \\
$\mathrm{~T}_{5}$ & $100 \% \mathrm{RDF}+\mathrm{FYM}+A p$. & 637.55 & 15.82 & 160.80 & 28.70 \\
$\mathrm{~T}_{6}$ & $75 \% \mathrm{RDF}+\mathrm{FYM}+A b .+A p$. & 933.30 & 17.50 & 180.04 & 44.10 \\
$\mathrm{~T}_{7}$ & $75 \% \mathrm{RDF}+A b .+A p$. & 800.90 & 13.51 & 138.99 & 11.25 \\
$\mathrm{~T}_{8}$ & $75 \% \mathrm{RDF}+\mathrm{FYM}+A b$. & 877.65 & 16.65 & 171.32 & 37.12 \\
$\mathrm{~T}_{9}$ & $75 \% \mathrm{RDF}+\mathrm{FYM}+A p$. & 879.75 & 14.15 & 145.52 & -0.47 \\
$\mathrm{~T}_{10}$ & $50 \% \mathrm{RDF}+\mathrm{FYM}+A b .+A p$. & 642.00 & 12.08 & 124.23 & -15.55 \\
$\mathrm{~T}_{11}$ & $50 \% \mathrm{RDF}+\mathrm{FYM}+A b$. & 480.70 & 9.87 & 101.51 & -14.01 \\
$\mathrm{~T}_{12}$ & $50 \% \mathrm{RDF}+\mathrm{FYM}+A p$. & 569.25 & 10.44 & 107.43 & -21.23 \\
$\mathrm{~T}_{13}$ & $50 \% \mathrm{RDF}+A b .+A p$. & 528.60 & 9.57 & 98.41 & -48.72 \\
$\mathrm{~T}_{14}$ & Control. & 372.70 & 6.22 & 64.07 & --- \\
& S.E. \pm & 58.70 & 1.37 & 5.31 & -- \\
\hline
\end{tabular}

of $75 \% \mathrm{RDF}+\mathrm{FYM}+$ Azotobacter + Azospirillum $\left(\mathrm{T}_{6}\right)$ while, rest of the treatments were at par except $\mathrm{T}_{11}, \mathrm{~T}_{12}, \mathrm{~T}_{13}$ and $\mathrm{T}_{14}$. The maximum days required (76.20 days) was in the treatment control $\left(T_{14}\right)$. Days required for curd maturity result showed that, the minimum days required for curd maturity (85.70 days) were in the treatment of $75 \% \mathrm{RDF}+\mathrm{FYM}+$ Azotobacter + Azospirillum $\left(\mathrm{T}_{6}\right)$ and it was at par with the treatments $\mathrm{T}_{7}, \mathrm{~T}_{2}, \mathrm{~T}_{10}, \mathrm{~T}_{8}, \mathrm{~T}_{3}, \mathrm{~T}_{4}, \mathrm{~T}_{5}$ and $\mathrm{T}_{1}$. The maximum period required for curd maturity (97.20 days) was recorded in the treatment control $\left(\mathrm{T}_{14}\right)$. The minimum days required for curd initiation and curd maturity was recorded in treatment of $75 \% \mathrm{RDF}+\mathrm{FYM}+$ Azotobacter + Azospirillum, $\left(\mathrm{T}_{6}\right)$. However, the maximum days required for curd initiation and curd maturity was recorded in treatment control $\left(\mathrm{T}_{14}\right)$. The probable reason for early curd initiation and curd maturity might be due to higher dose of $\mathrm{N}$ which was not effective as excess of $\mathrm{N}$ resulted in lodging by including an undue lengthening of stem internodes which delays the maturation of curds and also affects the curd quality. On the other hand, $\mathrm{P}$ nutrient could not be exerting significant effect on days taken for curd formation. Bio -fertilizers secreted hormones which enhances early curd initiation and curd maturity. Similar results have been reported by Sharma et al. (2002) in sprouting broccoli and Sable and Bhamare (2007) in cauliflower. These results are in accordance with the findings of Chatterjee et al. (2012) who reported that the application of inorganic fertilizers with organic manure and bio-fertilizers has significant effect on curd initiation and curd maturity.

The treatment of $75 \% \mathrm{RDF}+\mathrm{FYM}+$ Azotobacter + Azospirillum $\left(\mathrm{T}_{6}\right)$ recorded significant results with more staying capacity ( 9.25 days) and it was at par with treatments $T_{8}, T_{10}$ and $T_{1}$. The least staying period of curd (5.75 days) was observed in treatment control $\left(\mathrm{T}_{14}\right)$. This might be due to organic manure and Azotobacter and Azospirillum apart from nitrogen fixing potential produced plant growth hormones. These bacteria increased the activity of plant growth substances like Gibberellic acid, Indole acetic acid. While, by Azospirillum soil application plant might have responsible for increased vegetative growth which resulted in increasing staying period of curd. The similar trends of result was also reported by Gurav (2002) in cabbage and Sable and Bhamare (2007) in cauliflower who reported that the combination of inorganic fertilizers, organic manure and bio-fertilizers significantly increase the staying period of curd.

The data on the yield parameter indicated the significant differences. Curd yield per plot and yield per hectare observed significant variation in response to the levels of application of inorganic fertilizers with organic manure and bio-fertilizers. The treatment of 75 per cent RDF + FYM + Azotobacter + Azospirillum $\left(\mathrm{T}_{6}\right)$ recorded maximum yield in both yield per plot as well as yield per hectare (17.50 kg/plot, $180.04 \mathrm{q} / \mathrm{ha})$ and it was at par with the treatment $T_{2}(17.10 \mathrm{~kg} / \mathrm{plot}$, $175.92 \mathrm{q} / \mathrm{ha})$ and $\mathrm{T}_{8}(16.65 \mathrm{~kg} / \mathrm{plot}, 171.32 \mathrm{q} / \mathrm{ha})$. Lowest yield per plot as well as yield per hectare was recorded in treatment control $\left(\mathrm{T}_{14}\right)$ i.e. $6.33 \mathrm{~kg}$ per plot, $64.07 \mathrm{q}$ per ha. The per cent increase in yield over RDF was recorded maximum (44.10 per cent) in the treatment of $75 \%$ RDF+ FYM + Azotobacter + Azospirillum $\left(\mathrm{T}_{6}\right)$ while, followed by (40.80 per cent) in treatment of $100 \% \mathrm{RDF}+\mathrm{FYM}+$ Azotobacter + Azospirillum $\left(\mathrm{T}_{2}\right)$. The decrease in yield comparison with RDF ( -48.72 per cent) was recorded in treatment Control $\left(\mathrm{T}_{14}\right)$. The contribution of $75 \%$ RDF with FYM and bio-fertilizers to increase in yield can be attributed to the balanced $\mathrm{C}: \mathrm{N}$ ratio and enhanced availability of essential plant nutrient hence, increased rate and efficiency of metabolic activities resulting in higher assimilation of proteins and carbohydrates. The beneficial role of added FYM and bio-fertilizers in improving soil physical, chemical and biological properties was well known, which in turn helped in better 
nutrient absorption by the plant resulted in better yield. Increased in yield can also be attributed to sustained availability of nutrient throughout the growing season also efficacy of inorganic fertilizers is much pronounced when they were combined with organic manure and bio-fertilizers. Such beneficial effects of bio-fertilizers and inorganic fertilizers have been recorded by Chatterjee et al. (2012) in cabbage and Sable and Bhamare (2007) in cauliflower. The results of the present investigation revealed that the treatment receiving inorganic sources of nutrient with combination of bio-fertilizers was found to be best in all growth and yield parameters except leaf area per plant in cauliflower.

\section{Conclusion}

From the result of present investigation, it can be concluded that treatment of $75 \% \mathrm{RDF}+\mathrm{FYM}+$ Azotobacter + Azospirillum was found significantly superior in comparison with $100 \%$ RDF for getting maximum growth and yield of cauliflower production. The treatment of 75 \% RDF+FYM@10t/ha + Azotobacter@ $10 \mathrm{~kg} / \mathrm{ha}+$ Azospirillum @10 kg/ha was proved to be the optimum combination of inorganic and biofertilizer for improving the yield in cauliflower. Resource poor farmers who are unable to apply full dose of recommended fertilizer may apply $75 \%$ of recommended dose of fertilizers along with bio-fertilizers in balanced way to maximize yield of crop and almost save the 25 per cent of the cost of fertilizers.

\section{ACKNOWLEDGEMENTS}

The authors are thankful to The Head, Department of Horticulture, College of Agriculture, Latur, under Vasantrao Naik Marathawada krishi vidyapeeth Parbhani, Maharashtra, for the facilities provided during the experiment.

\section{REFERENCES}

Anonymous (2014). Indian Horticulture Database, National Horticulture Board, Govt. of India retrieved from http:// www.nhb.gov.in.

Chattergee, R., Jane, J. C. and Paul, P. K. (2012). Enhancement of head yield and quality of cabbage (Brassica oleracea) by combining different sources of nutrients, Indian J. of Agril Sci., 82(4):323-327

Gurav, A. D. (2002). Effect of bio-fertilizer (Azotobacter and Azospirillum) alone and in combination with reducing levels of nitrogen on growth and yield of cabbage. M.Sc.(Agri.) Thesis. MKV. Parbhani (Unpublished).

Mondal, T., Ghanti, P., Mahato, B., Mondal, A. R. and Thapa, U. (2003). Effect of spacing and biofertilizer on yield and yield attributes of direct sown Chilli (C. annuum L. Cv Bona Lanka). Env. Eco., 21:712-15

Mishra, P. and Dash, D. (2014). Rejuvenation of bio-fertilizer for sustainable agriculture and economic development. JSD, 11(1): 41-61

Nanjappa, H. P., Ramchanrappa, B. K. and Mallikarjuna, B. O. (2001). Effect of integrated nutrient management on yield and nutrient balance in maize. Indian J. Agron., 46 (4): 668-701

Panse, V. G. and Sukhatme, P. V. (1967). Statistical method of agricultural workers. Published by I. C. A. R., New Delhi.

Peerzada, I. A., Kumar, V. and Malik, M. F. (2009). Effect of bio-organic fertilizer on Preformance on cabbage under western U. P. Conditions. Annal Horti., 2(2):5559

Purkayastha, T. J., Singh, C. S. and Chhonkar, P. K. (1998). Growth and iron nutrient of broccoli grown in a typic ustochrept as influenced by VAM fungi in presence of pyrite and farmyard manure. Biol. Fert. Soil., 27(1): $45-48$

Randhawa, K. S. and Khuraha, D. S. (1983). Effect of nitrogen, phosphorus and potassium fertilization on the yield and quality of cauliflower. Veg. Sci., 10(1): 1-7

Roy, H. K. (1981). Effect of nitrogen on curd size and yield of cauliflower. Veg. Sci., 8(2): 75-78

Sable, P. S. and Bhamare, V. K. (2007). Effect of biofertilizers (Azotobacter and Azospirill) alone and in combination with reduced level of nitrogen on quality of Cauliflower Cv. Snowball-16..Asian J. Hort., 2(1):215-217

Savci, S. (2012). An agricultural pollutant: chemical fertilizer, IJESD., 3(1):77-80

Sharma, S.K., Sharma, R. and Korla, B.N. (2002). Rresponce of $\mathrm{N}$ and $\mathrm{P}$ on growth and yield of sprouting broccoli (Brassica oleracea var. italica.), Indian J. Hort., 59(3): 313-315

Shree, S., Kumar, V. and Kumar, R. (2014). Effect of integrated nutrient management on yield and quality of cauliflower (brassica oleracea var.botrytis L.), The Bioscan, 9 (3): 1053-1058 